\title{
TEACHING INDONESIAN AS A FOREIGN LANGUAGE THROUGH SMALL PRIVATE ONLINE COURSE (SPOC): INVESTIGATING LEARNERS' MULTIDIMENSIONAL ANXIETY IN ONLINE LEARNING
}

\author{
Darmawansah \\ Graduate Institute of Digital Learning and Education \\ National Taiwan University of Science and Technology \\ e-mail: darmawansahlavoe@gmail.com
}

\begin{abstract}
One of the foreign language learners challenges is the anxious level they mostly face while learning a new language. Even though Foreign Language Anxiety (FLA) has been analyzed for decades to foresee language learners' challenges in the learning process, the previous results only focus on single language skills and the offline learning environment. In consideration, learning a foreign language is supposed to be a multidimensional analysis and forced to be online due to the current pandemic. Thus, this study investigates how Taiwanese learners face FLA when learning Indonesian as A Foreign Language (IFL) through Small Private Online Course (SPOC). Participants were assessed by Multimedimensional Language Anxiety Scale (MLAS) at the end of their six-months course. The results showed that writing was the highest anxiety while reading was the lowest anxiety. The psychology domain that showed the learners tension during learning IFL through SPOC revealed the most highly anxious. Surprisingly, nearly two-thirds of learners were considered overall moderate-level anxiety by using SPOC as a learning platform. In further investigation, male learners dominated each foreign language skills and domains' anxiety level compared to female learners. The correlations among language skills and domains are presented and critically discussed. Finally, it opens more opportunities to explore SPOC and another online learning platform to reduce learners' FLAs.
\end{abstract}

Keywords: Indonesian as a foreign language, multidimensional language anxiety, online learning, spoc

\section{PENGAJARAN BAHASA INDONESIA UNTUK PENUTUR ASING MELALUI SMALL PRIVATE ONLINE COURSE (SPOC): INVESTIGASI KECEMASAN MULTIDIMENSIONAL BAHASA DI PEMBELAJARAN DARING}

\begin{abstract}
Abstrak
Salah satu tantangan pemelajar bahasa asing adalah tingkat kecemasan yang paling sering mereka hadapi selama belajar bahasa baru. Meskipun kecemasan berbahasa asing (FLA) telah dianalisis selama beberapa dekade untuk melihat tantangan para pembelajar bahasa asing dalam proses pembelajaran, sebagian besar hasil dari penelitian sebelumnya hanya fokus pada satu keterampilan bahasa saja dan pembelajaran non-daring, sementara belajar bahasa asing seharusnya menjadi sebuah analisis yang multidimensional dan pendekatan daring terutama di kondisi pandemik. Sebagai solusi, studi ini menyelidiki bagaimana mahasiswa Taiwan menghadapi kecemasan bahasa asing melalui pembelajaran daring. Para mahasiswa dinilai dengan menggunakan skala kecemasan multidimensional bahasa (MLAS) di akhir masa enam bulan belajar Bahasa Indonesia mereka. Hasil penelitian menunjukkan bahwa menulis menjadi kecemasan tertinggi sementara membaca adalah kecemasan yang paling rendah. Selain itu, domain psikologi yang menunjukkan ketegangan mahasiswa selama belajar Bahasa Indonesia melalui penggunaan small private online course (SPOC) sebagai yang sangat menggelisahkan. Secara mengejutkan, hampir dua pertiga mahasiswa yang menggunakan SPOC dalam pembelajaran dianggap secara keseluruhan tingkat kecemasannya dalam tingkat sedang. Lebih lanjut, pembelajar pria mendominasi tingkat kecemasan di setiap kompetensi bahasa dan domain. Hubungan antar variabel kompetensi bahasa dan domain juga dibahas secara kritis. Pada akhisnya, study ini membuka lebih banyak peluang untuk mengekplorasi SPOC dan platform pembelajaran online lainnya untuk mengatasi kecemasan berbahasa asing para pembelajar.
\end{abstract}

Kata Kunci: bahasa indonesia untuk penutur asing, kecemasan multidimensional bahasa, pembelajaran daring, spoc

\section{PENDAHULUAN}

Foreign Language Anxiety (FLA) concerns analyzing learners' suffering when learning a foreign language (Atas, 2015; Dörnyei \& Ryan, 2015). Previous research stated that are few variables considered to affect L2 anxiety among learners. These variables include prior knowledge and academic performance (Sinnasamy \& Karim, 2015), gender preferences (Çağatay, 2015; Ra 
\& Rhee, 2018; Razak, Yassin, \& Maasum,2017), and socio-emotional development (De Costa, 2015; Piniel \& Albert, 2018). Moreover, most of the studies argue that intervening learning by the specific tool is needed to degrade learners' anxiety while learning a foreign language (Hamzaoğlu \& Koçoğlu， 2016; Liao \& Wang, 2018; Sinnasamy \& Karim, 2015). As a result, the negative occurrence might get neglected by teachers and learners across all language activities.

Unlike English or other well-known languages that have been learned as a second and foreign language for ages, the Indonesian language has widely begun its 'diplomacy' to be taught within Asian countries (Kusmiatun, Suyitno, \& Basuki, 2017). In Taiwan's case, the Taiwanese Ministry of Education (MOE) would require K-12 learners to choose whether learning a Taiwanese native language or immigrants' language, including the Indonesian language, in their school. They are planning to adopt the Indonesian language in the 12-year compulsory education curriculum. MOE argued a high demand for Indonesian language teachers $(18 \%)$ in the country (Liao, 2017). To respond to the demand, the Indonesian language becomes one of the foreign languages that Taiwanese higher education offers to attract local learners.

Moreover, the Indonesian language has undoubtedly been an expressive language for local learners. It is due to the increasing number of migrants who currently work and study in Taiwan. Indonesian migrants become one of the largest groups amongst others who have settled in Taiwan; thus, the Indonesian language is easy to find in every Taiwanese public information and other immigrants languages. Thus, Taiwanese higher education has opened the Indonesian language class as one of the offered-elective courses in their foreign language department and perceived several issues revealed in learning the Indonesian language for Taiwanese learners.

One of the tools that may play a meaningful to learn a foreign language is an online platform. Warschauer and Healey
(1998) stated how technology platforms such as online learning aim to facilitate the teaching process for learners who cannot learn from native speakers straightway. It makes many studies held research in this area. As a result, online learning terms such as blended learning, distance learning, Massive Open Online Course (MOOC), and SPOC surfaces bring new perspectives on online learning. In the higher education context, SPOC was argued to bring better results than a previous well-known term such as MOOC. It is believed that learners' participation rate and the completion rate is high (Guo, 2017). Even though technology in online learning can intrigue learners with a massive opportunity to embrace authentic content (Godwin-jones, 2005), the effects of L2 anxiety have still mixed as current studies indicate their results to be unanswered questions for several reasons (Aydın, 2018). Horwitz (2010) argued that anxiety is the most critical variable for foreign language learners, which is a state of emotional learners' perception during the process. Thus, it is a significant inquiry for current studies to overcome this issue (Blau, 1955). Accordingly, the following research question was examined to validate how multidimensional foreign language anxiety affects learners' online learning performance.

\section{LITERATURE REVIEW}

The Influence of Small Private Online Course SPOC was firstly introduced by Fox (2013) to distinguish between MOOC and SPOC. SPOC means 'private broadcast class,' which is considered the university classroom application process (Guo, 2017). Compared to MOOC, which is massively open for everyone, SPOC is a curriculum model that applies online teaching resources that swipes over the traditional classroom on campus (Fox et al., 2014). This 'switching' model has brought many colleges and universities to play SPOC as an essential role in designing their renewedcurriculum.

The rise of online learning has prompted the role of SPOC in the educational technology 
field significantly. Blended and flipped learning are some of the teaching models which get analyzed in the SPOC environment. Jong (2016) argues that teacher's intervention is needed while learners shift their focus into learning materials (e.g., video, comment box, and technical issue) in a blended learning model. In most cases, online learning limitation includes the lack of timely feedback that learners receive anytime. In contrast, SPOC presents crucial components that allow teachers to monitor learners' learning progress. The restriction access also provides a small number of learners so that learners' feedback can be more per capita and more timely (Guo, 2017). Thus, it shows opportunities for SPOC to be a solution for online learning issues.

\section{Indonesian as A Foreign Language (IFL) and Its Current Issue}

The previous studies perform various strategies and media to enhance learners' performances (Murtianis, Andayani, \& Rohmadi, 2019; Saddhono \& Erwinsyah, 2018; Setiawan, Andayani, \& Saddhono, 2017; Suyitno, Susanto, Kamal, \& Fawzi, 2018). For instance, the textbook is believed to be the primary learning media towards learners (Murtianis et al., 2019; Setiawan et al., 2017). It is due to the tailoring of IFL learning for adult learners whose individual characteristic has been evolved. However, these strategies and media were given to learners with limited prior knowledge of learners' cognitive and emotional states. Even though the aforementioned studies were done in the classroom, learners' emotional were easily observed. As a comparison, online learning becomes problematic to engage learners where impulsive engagement between learners and instructions seems unattainable.

Unlike L1, IFL learning as L2 is significantly challenging for learners with various language and cultural backgrounds (Ramadhani, \& Harsiati, 2016). It encourages the previous study to develop learning materials to cope with the learners' needs for learning IFL (Kurniasih \& Isnaniah, 2019). On the other hand, learners who learn IFL need to have a ready platform designed for a specific group of learners.

\section{The Actualization of Multidimensional Language Anxiety}

The studies mentioned above, which mainly found learners' factors of anxiety, answer how diversity existed in learning. Following the previous studies, each domain of language has been affected due to learners' anxiety. Language domains such as reading (Zhao, Guo, \& Dynia, 2013), listening (Mills, Pajares, \& Herron, 2006), speaking (Yalçın \& İnceçay, 2014), and writing (Qashoa, 2014) negatively show learners' performance correlated to the anxiety level. One intervention to overcome learners' anxiety was using game-based learning. Yang \& Quadir (2018) suggest game-based learning's benefit to support language learning. Along with other studies, game-based learning documented how advancing each strategy to adverse its effects even though the results showed that the removal of anxiety level is limited.

One of the strategies to overcome learners' level of anxiety is online learning intervention. It has been massively using as acquiring academic in higher education (Soffer \& Nachmias, 2018). Heckel and Tobias (2019) state that features are the most concern in the online learning environment. Some features include automated feedback and specific usability, which are argued to enhance learners' outcomes. However, most available studies only focus on learners' cognitive achievement (Frantzen, 2014) due to reducing learners' emotions when engaging in the online learning environment. As a result, learners mostly face the challenge of regulating their own learning pace and emotional per se, which are supposedly significant for further studies.

Furthermore, from a pedagogical perspective, it is urgently required for each related-parties to understand how cognitive and emotional achievement can respond to learners' competence in learning a foreign language. This study presents learners' emotional arrangements through language anxiety to support the argument. 
Unlike previous studies, which focused on mostly single language skills, this study embodied three foreign language domains to measure each skill. It has the insight of cognitive, affective, and psychological approaches in online learning. Originally, Kutuk et al. (2019) developed their specific language anxiety domains in five language skills. Unfortunately, speaking was not included in this study since the current learning platform does not provide speaking interaction. However, speaking skill has been entirely concerned by Horwitz, Horwitz, and Cope (1986) through their Foreign Language Classroom Anxiety Scale (FLCAS), which is mainly focus on the learners skill in speaking. The previous studies have emphasized the role of each significant skills in foreign language learning. On the other hand, the lack of studies in teaching IFL has made this study turns positively for any parties who are interested in this particular area

\section{METHODS}

The participants were from two Taiwanese higher education in Northern Taiwan. The total of participants was 29 learners who enrolled in the foreign language department and various departments, including engineering, business, and management. They took the IFL online course (A1 level) for six months. It was a fully online learning course that is limited only for learners from both universities. The data was taken at the end of the semester (January 2020) by adopting Kutuk et al. (2019) questionnaire of multidimensional language anxiety scale.

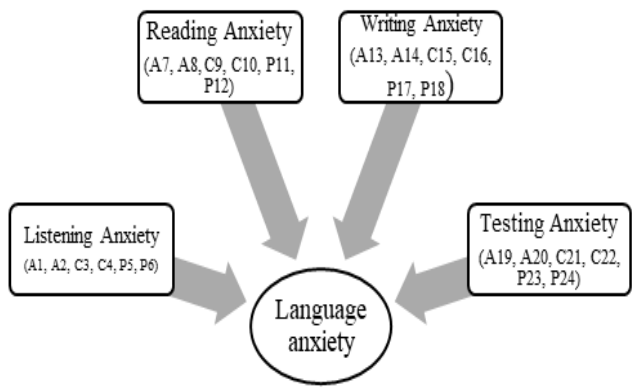

Figure 1. Modified-bifactor model of multidimensional language anxiety (Kutuk et al., 2019)
The questionnaire consists of 24 items attributed to each L2 skills (listening, reading, writing, and testing) and domains (cognitive, affective, and psychological items). Speaking is another item removed in this study since the platform cannot provide a particular skill. The questionnaire is a 5-point Likert scale from which a higher score level indicates a higher level of anxiety. Besides, the item was translated into Chinese (traditional) language to ensure learners understand each item. This scale has been reported in the most reliable measurement with Cronbach $\alpha=.86$, indicating high internal consistency. To extend, male and female learners' anxiety was analyzed and correlated to each variable to validate the initial analysis.

All necessary data were coded into IBM SPSS version 20 for statistical analysis. Each participant was given a code, and their responses were coded into SPSS to examine their anxiety level. Furthermore, descriptive analysis was presented as four skills and domains were calculated.

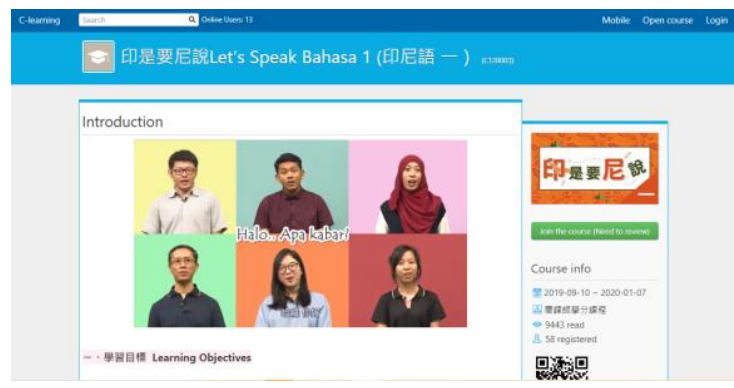

Figure 2. IFL course interface on SPOC

\section{RESULT AND DISCUSSION}

\section{IFL Anxiety Level Among Learners}

Determining the learners' level of anxiety is the first step in this study. All participants' responses were added and divided by the total number of 24-items of MLA (Kutuk et al., 2019). By giving 1 to 5 scale of FLA, the learners' scores were set around or above three are anxious while learners whose score below three should be moderate anxious. Hence, the four skills table below determines learners' MLA as measured by mean, standard 
deviation, median, and mode. This table was calculated using SPSS version 20.

Table 1. The Overall MLA scores in IFL SPOC

\begin{tabular}{lccc}
\hline $\begin{array}{c}\text { Language } \\
\text { skills }\end{array}$ & Mean & SD & Median \\
\hline Listening & 2.64 & .93 & 3.00 \\
Reading & 2.46 & .88 & 2.50 \\
Writing & 3.02 & .99 & 3.00 \\
Testing & 2.93 & .97 & 3.00 \\
Overall & 2.76 & .94 & 2.87 \\
\hline
\end{tabular}

As shown in the above table, listening skill has a mean score of $2.64(\mathrm{SD}=.93)$ with both median and mode are 3.00 , which were around and above the average mean score (3.00). Moreover, the most common value in this skill was $3.00(42 \%)$. Another skill is reading, which means the score valued 2.46 $(\mathrm{SD}=.88)$. Reading's three parameters were lower than 3.00, which means learners' anxiety in learning IFL is not as anxious as listening skills. The frequency dataset shows 3.00 was the most input (39\%) and 2.00 left-right behind with $31 \%$. This data revealed a further fact that learners' reading anxiety is low.

Writing is still another skill to be analyzed its level. The mean score was 3.02 $(\mathrm{SD}=.99)$, with each median was 3.00 , which means learners' writing anxiety was above medium. The frequency value also shows $33.3 \%$ out of $100 \%$ was 3.00. Furthermore, the value of 4.00 was $25.9 \%$ to be chosen by learners. It can be assumed that writing anxiety among learners was above the average mean. The other skill is testing in learning IFL. Its mean score is $2.93(\mathrm{SD}=94)$ with both Median and More were 3.00, which confirms the anxiety level around an average mean value. The frequency dataset value also supports it in $3.00(37.9 \%)$ and above-average value of 4.00 $(28.2 \%)$.

This study proceeds to analyze three different domains covered by MLA. Unlike the previous FLA domain, MLA mainly differentiated among affective, cognitive, and psychological anxieties in terms of emotional understanding in both the nature of FL learners' suffering and the teacher further appropriately strategies to help the anxiety of FL learners (Kutuk et al., 2019). The result of the analysis is shown below.

Table 2. Domain situation of MLA in IFL SPOC

\begin{tabular}{cccc}
\hline Domain & Mean & SD & Median \\
\hline Affective & 2.40 & .77 & 2.56 \\
Cognitive & 2.56 & .94 & 3.00 \\
Psychology & 3.67 & .90 & 2.70 \\
Overall & 2.87 & .87 & 2.75 \\
\hline
\end{tabular}

The above table clearly shows effective is the less anxious for learners who learn IFL. The affective domain had a mean score of 2.40 $(\mathrm{SD}=.77)$ with median and mode are sequence 2.56 and 2.67, which its frequency revealed that the average learners' score was 3.00 $(41.5 \%)$. As a result, it seems to be moderate learners anxious in the affective domains.

Another cognitive domain, which mean valued $2.56(\mathrm{SD}=.94)$ with a $35.4 \%$ frequency, then its median value 3.00 . It shows that learners' cognitive anxiety is fair to moderate. The last domain was psychology. This domain had a mean score of $3.67(\mathrm{SD}=.90)$, a median is 2.70 . For this component, it is revealed that the psychology domain is the highest peak of learners' anxiety, among others.

Finally, the 24-items MLA statistic discloses a mean score of $2.87(\mathrm{SD}=.87)$, a median of 2.56. It is a final correspondent to the three-parameter domains above, which analytically describes learners' average score of 3.00. These results were the learners' overall image of the extent to which they suffer from IFL anxiety.

In terms of creating, learners' anxiety level examination is essential based on MLA mean results. Learners' raw score was further converted to z-scores. It aims to classify the learners' three anxiety levels from the low to the high anxiety levels. The highly anxious was for the learners whose $\mathrm{z}$-score were one or more than one SD above the MLA mean, whereas the least anxious was for those whose z-score were one or more than one SD below the mean. Learners with moderately anxious were learners whose z-scores were within an $\mathrm{SD}$ of the mean. 
Table 3. Mean MLA by Anxiety Level using z-

\begin{tabular}{ccccc}
\begin{tabular}{c} 
score \\
\hline $\begin{array}{c}\text { Anxiety } \\
\text { level }\end{array}$
\end{tabular} & $\mathbf{n}$ & $\boldsymbol{\%}$ & Mean & SD \\
\hline High & 2 & 7 & 4.15 & .37 \\
Medium & 18 & 62 & 3.11 & .33 \\
Low & 9 & 31 & 1.81 & .67 \\
\hline
\end{tabular}

The table above displays that most learners were suffering from a moderate degree of anxious (62\%) to the least degree of anxious (31\%). There were only two learners whose possible anxiety are considered highly anxious. This finding also revealed that nearly twothirds of Taiwanese higher education learners were experiencing medium-anxiety of learning IFL through SPOC, indicating SPOC as an alternative language learning tool for L2 learners.

To extend gender difference and correlation analysis, table 4 displays each correlation between items towards male and female learners. All of the items show a strong and positive relationship for both statistically significant genders. Thus, the performed-data on language skills and domains are associated with the learners by their genders. Similar data is also displayed in table 5 , in which female learners performed higher MLA compared to male learners in listening, reading, writing, affective, cognitive, and psychology. However, male learners do not show significant different in listening test $(p>.05)$, and reading test $(p>.05)$, while writing test has significant different $(p<0.19)$.

\section{CLOSING}

The results above imply several pedagogical values that need to be considered. This study shows that learning media could bring a vigorous effort for learners to learn a foreign language and disregarded language anxiety beliefs. Furthermore, this finding undermines the hypothesis that MLA is validated to be applied in online learning. Even though few learners were suffering anxious, learners' anxiety was mostly debilitative by implementing SPOC. To a great extent, the study has confirmed Fox's argument (2013) towards SPOC benefits in online platforms' efficiency, and they were impressed by its instruction to result in anxious reducing.

Among the three domains, most learners were suffering from psychological aspects that covered the tense and learners' heart race during the learning. However, it does not necessarily result in highly anxious. The fact is that the learners' grades might be a high consequence of the course dynamic at SPOC. Thus, a teacher or instructor of SPOC must provide constant feedback for each individual as much as an encouragement to lowering anxiety levels. As this study shows, feeling some tension is part of the complexity in learning a foreign language. It would be very much enjoyable if future FLA studies could prove whether a more standard online platform facilitates or undermines learners to overcome FLA to lead success or failure learning. FLA is indeed highly context-oriented, so there is always the relationship between FLA and learning media used. 
Table 4. Items' correlation towards learners' gender

\begin{tabular}{|c|c|c|c|c|c|c|}
\hline \multicolumn{2}{|c|}{ Items } & \multirow{2}{*}{\begin{tabular}{|c|} 
Mean \\
Ranks \\
8.17
\end{tabular}} & \multirow{2}{*}{$\begin{array}{l}\text { Min } \\
1.00\end{array}$} & \multirow{2}{*}{$\begin{array}{l}\text { Max } \\
4.33\end{array}$} & \multirow{2}{*}{$\begin{array}{c}\mathrm{Z} \\
-3.718^{* *}\end{array}$} & \multirow{2}{*}{$\begin{array}{c}\begin{array}{c}\text { Asymp.Sig } \\
\text { (2-tailed) }\end{array} \\
.000\end{array}$} \\
\hline Listening & Negative & & & & & \\
\hline & Positive & 13.66 & & & & \\
\hline \multirow[t]{2}{*}{ Reading } & Negative & 12.00 & 1.00 & 4.33 & $-3.263 * *$ & .001 \\
\hline & Positive & 12.57 & & & & \\
\hline \multirow[t]{2}{*}{ Writing } & Negative & 7.00 & 1.00 & 4.60 & $-4.115^{* *}$ & .000 \\
\hline & Positive & 14.04 & & & & \\
\hline \multirow[t]{2}{*}{ Testing } & Negative & 6.00 & 1.00 & 5.00 & $-4.161 * *$ & .000 \\
\hline & Positive & 14.13 & & & & \\
\hline \multirow[t]{2}{*}{ Affective } & Negative & 11.60 & .89 & 3.89 & $-3.306^{* *}$ & .000 \\
\hline & Positive & 15.13 & & & & \\
\hline \multirow[t]{2}{*}{ Cognitive } & Negative & 7.00 & 1.00 & 4.50 & $-4.041 * *$ & .000 \\
\hline & Positive & 14.88 & & & & \\
\hline \multirow[t]{2}{*}{ Psychology } & Negative & 9.50 & 1.00 & 4.71 & $-3.736^{* *}$ & .000 \\
\hline & Positive & 14.02 & & & & \\
\hline
\end{tabular}

$* * p<.01, * * * p<.00$

Table 6. Correlations of students' gender and their Indonesian language skills and domains

\begin{tabular}{|c|c|c|c|c|c|c|c|c|}
\hline $\begin{array}{l}\text { Student } \\
\text { s' }^{\prime} \\
\text { gender }\end{array}$ & $\begin{array}{l}\text { Spearman } \\
\text { Rho } \\
\text { Coefficien } \\
\mathrm{t}(p)\end{array}$ & $\begin{array}{l}\text { Listenin } \\
\mathrm{g}\end{array}$ & $\begin{array}{l}\text { Readin } \\
\mathrm{g}\end{array}$ & $\begin{array}{l}\text { Writin } \\
\mathrm{g}\end{array}$ & $\begin{array}{l}\text { Testin } \\
\mathrm{g}\end{array}$ & $\begin{array}{l}\text { Affectiv } \\
\text { e }\end{array}$ & $\begin{array}{l}\text { Cognitiv } \\
\mathrm{e}^{\text {Con }}\end{array}$ & $\begin{array}{l}\text { Psycholog } \\
\text { y }\end{array}$ \\
\hline \multirow{11}{*}{ Male } & Listening & - & & & & & & \\
\hline & Reading & $\begin{array}{l}.953 * * \\
.003\end{array}$ & - & & & & & \\
\hline & Writing & $.926 * *$ & $.971 * *$ & - & & & & \\
\hline & & .008 & .001 & & & & & \\
\hline & Testing & .802 & $\begin{array}{l}.794 \\
050\end{array}$ & $.886^{*}$ & - & & & \\
\hline & Affective & $.926 * *$ & $.971 * *$ & $1.000 *$ & $.886^{*}$ & - & & \\
\hline & & .008 & .001 & $*$ & .019 & & & \\
\hline & Cognitive & $.926 * *$ & $.971 * *$ & $1.000^{*}$ & $.886^{*}$ & $1.000 * *$ & - & \\
\hline & & .008 & .001 & $*$ & .019 & . & & \\
\hline & Psycholog & $.890 *$ & $.955 * *$ & $.971 * *$ & $.912 *$ & $.971 * *$ & $.971 * *$ & - \\
\hline & $\mathrm{y}$ & .018 & .003 & .001 & .011 & .001 & .001 & \\
\hline \multirow[t]{9}{*}{ Female } & Listening & - & & & & & & \\
\hline & Reading & $\begin{array}{l}.690 * * \\
.000\end{array}$ & - & & & & & \\
\hline & Writing & $\begin{array}{l}.734 * * \\
.000\end{array}$ & $\begin{array}{l}.530 * * \\
.009\end{array}$ & - & & & & \\
\hline & Testing & $\begin{array}{l}.805 * * \\
.000\end{array}$ & $\begin{array}{l}.684 * * \\
.000\end{array}$ & $\begin{array}{l}.886^{* *} \\
.000\end{array}$ & - & & & \\
\hline & Affective & $.876^{* *}$ & $.759 * *$ & $.868 * *$ & $.934 * *$ & - & & \\
\hline & & .000 & .000 & .000 & .000 & & & \\
\hline & Cognitive & $\begin{array}{l}.872 * * \\
.000\end{array}$ & $\begin{array}{l}.747 * * \\
.000\end{array}$ & $\begin{array}{l}.856^{* *} \\
.000\end{array}$ & $\begin{array}{l}.886^{*} \\
.000\end{array}$ & $\begin{array}{l}.885^{* *} \\
.000\end{array}$ & - & \\
\hline & Psycholog & $.905^{* *}$ & $.799 * *$ & $.761 * *$ & $.895^{* *}$ & $.915 * *$ & $.872 * *$ & - \\
\hline & y & .000 & .000 & .000 & .000 & .000 & .000 & \\
\hline
\end{tabular}




\section{REFERENCES}

Atas, M. (2015). The reduction of speaking anxiety in EFL learners through drama techniques. Procedia-Social and Behavioral Sciences, 176, 961-969.

Aydın, S. (2018). Technology and foreign language anxiety: Implications for practice and future research. Dil ve Dilbilimi Çalışmaları Dergisi, 14(2), 193-211.

Blau, A. (1955). A unitary hypothesis of emotion: I. Anxiety, emotions of displeasure, and affective disorders. The Psychoanalytic Quarterly, 24(1), 75103.

Çağatay, S. (2015). Examining EFL students' foreign language speaking anxiety: The case at a Turkish state university. Procedia-Social and Behavioral Sciences, 199, 648-656.

De Costa, P. I. (2015). Reenvisioning language anxiety in the globalized classroom through a social imaginary lens. Language Learning, 65(3), 504532.

Dörnyei, Z., \& Ryan, S. (2015). The psychology of the language learner revisited. Routledge.

Fox, A. (2013). From MOOCS to SPOCS. Communications of the ACM, 56(12), 38-40.

Fox, A., Patterson, D. A., Ilson, R., Joseph, S., Walcott-Justice, K., \& Williams, R. (2014). Software engineering curriculum technology transfer: lessons learned from MOOCs and SPOCs. UC Berkeley EECS Technical Report.

Frantzen, D. (2014). Is technology a one-sizefits-all solution to improving student performance? A comparison of online, hybrid and face-to-face courses. Journal of Public Affairs Education, 20(4), 565578.

Godwin-jones, R. (2005). Skype and podcasting: Disruptive technologies for language learning. Language learning \& technology, 9(3), 9-12.

Guo, P. (2017). MOOC and SPOC, which one is better?. Eurasia Journal of Mathematics, Science and Technology Education, 13(8), 5961-5967.

Hamzaoğlu, H., \& Koçoğlu, Z. (2016). The application of podcasting as an instructional tool to improve Turkish EFL learners' speaking anxiety. Educational

Media

International, 53(4), 313-326.

Heckel, C., \& Ringeisen, T. (2019). Pride and anxiety in online learning environments: Achievement emotions as mediators between learners' characteristics and learning outcomes. Journal of Computer Assisted Learning, 35(5), 667-677.

Horwitz, E. K. (2010). Foreign and second language anxiety. Language Teaching, 43(2), 154.

Horwitz, E. K., Horwitz, M. B., \& Cope, J. (1986). Foreign language classroom anxiety. The Modern language journal, 70(2), 125-132.

Jong, J. P. (2016). The effect of a blended collaborative learning environment in a small private online course (SPOC): A comparison with a lecture course. Journal of Baltic Science Education, 15(2), 194.

Kurniasih, D., \& Isnaniah, S. (2019). Penerapan Bahan Ajar Bahasa Indonesia bagi Penutur Asing (BIPA) "Sahabatku Indonesia" Tingkat Dasar di IAIN Surakarta. Jurnal Bahasa Indonesia Bagi Penutur Asing (JBIPA), 1(2), 62. https://doi.org/10.26499/jbipa.v1i2.1793

Kusmiatun, A., Suyitno, I., HS, W., \& Basuki, I. A. (2017). Identifying features of Indonesian for speakers of other languages (BIPA) learning for academic purposes. International Journal of Social Sciences \& Educational Studies, 3(4), 197.

Kutuk, G., Putwain, D. W., Kaye, L., \& Garrett, B. (2019). Development and Validation of a New Multidimensional Language Class Anxiety Scale. Journal of Psychoeducational Assessment, 38(5), 649-658.

Liao, G. (2017). Teachers of Vietnamese and Indonesian languages to be in greater demand in Taiwan | Taiwan News. Retrieved January 6, 2020, from https://www.taiwannews.com.tw/en/new s/3174536

Liao, H. C., \& Wang, Y. H. (2018). Using comprehension strategies for students' self-efficacy, anxiety, and proficiency in reading English as a foreign language. Social Behavior and Personality: an international journal, 46(3), 447-458.

Mills, N., Pajares, F., \& Herron, C. (2006). A 
reevaluation of the role of anxiety: Selfefficacy, anxiety, and their relation to reading and listening proficiency. Foreign language annals, 39(2), 276-295.

Murtianis, M., Andayani, A., \& Rohmadi, M. (2019). Text Book As a Java Culture Recognition Media in Indonesian Learning For Foreign Speaker (BIPA) in Sebelas Maret University. International Journal of Educational Research Review, 4(3), 427-434.

Piniel, K., \& Albert, Á. (2018). Piniel, K., \& Albert, Á. (2018). Advanced learners' foreign language-related emotions across the four skills. Studies in Second Language Learning and Teaching, 8(1).

Qashoa, S. H. H. (2014). English writing anxiety: Alleviating strategies. Procedia-Social and Behavioral Sciences, 136, 59-65.

Ra, J., \& Rhee, K. J. (2018). Detection of Gender related DIF in the Foreign Language Classroom Anxiety Scale. Educational Sciences: Theory \& Practice, 18(1).

Ramadhani, R., Hs, W., \& Harsiati, T. (2016). Pengembangan bahan ajar keterampilan berbicara bahasa Indonesia bagi penutur asing tingkat pemula. Jurnal Pendidikan: Teori, Penelitian, dan Pengembangan, 1(3), 326-337.

Razak, N. A., Yassin, A. A., \& Mohamad Maasum, T. N. R. B. T. (2017). Effect of Foreign Language Anxiety on Gender and Academic Achievement among Yemeni University EFL Students. English Language Teaching, 10(2), 73-85.

Saddhono, K., \& Erwinsyah, H. (2018). Folklore As Local Wisdom for Teaching Materialsin Bipa Program (Indonesian for Foreign Speakers). KnE Social Sciences, 444-454.

Setiawan, A. M. N., Andayani, A., \& Saddhono, K. (2017). The Use of Writing Learning Media For Bipa Students To
Understand Local Culture. Komposisi: Jurnal Pendidikan Bahasa, Sastra, dan Seni, 18(1), 66-79.

Sinnasamy, J., \& Karim, N. H. A. (2015). Academic related anxieties: A case study investigating the relationships among library, communication and language anxieties among non-native speakers of English. Malaysian Journal of Library \& Information Science, 20(2).

Soffer, T., \& Nachmias, R. (2018). Effectiveness of learning in online academic courses compared with faceto-face courses in higher education. Journal of Computer Assisted Learning, 34(5), 534-543.

Suyitno, I., Susanto, G., Kamal, M., \& Fawzi, A. (2018). Cognitive Learning Strategy of BIPA Students in Learning the Indonesian Language. IAFOR Journal of Language Learning, 3(2), 175-190.

Warschauer, M., \& Healey, D. (1998). Computers and language learning: An overview. Language teaching, 31(2), 5771.

Yalçın, Ö., \& İnceçay, V. (2014). Foreign language speaking anxiety: The case of spontaneous speaking activities. Procedia-Social and Behavioral Sciences, 116, 2620-2624.

Yang, J. C., \& Quadir, B. (2018). Effects of prior knowledge on learning performance and anxiety in an English learning online role-playing game. Journal of Educational Technology \& Society, 21(3), 174-185.

Zhao, A., Guo, Y., \& Dynia, J. (2013). Foreign language reading anxiety: Chinese as a foreign language in the United States. The Modern Language Journal, 97(3), 764-778. 